\title{
PENDIDIKAN DAN SUMBER INFORMASI TERHADAP PENGETAHUAN IBU TENTANG ALAT PERMAINAN YANG MERANGSANG MOTORIK BALITA
}

\author{
Nurhanifah Siregar ${ }^{1}$,Susi Febriani Yusuf ${ }^{2}$ \\ 1,2 STIKes Darmais Padangsidimpuan, Padangsidimpuan, Indonesia \\ Email: ${ }^{1}$ nurhanifahsiregar90@gmail.com, ${ }^{2}$ febrianiyusuf44@gmail.com
}

\begin{abstract}
ABSTRAK
Alat permainan mempunyai pengaruh yang cukup besar terhadap tumbuh kembang anak. Namun kenyataannya permainan yang menyebar dimasyarakat lebih banyak didominasi permainan non-edukatif sehingga tidak sedikit mainan yang diproduksi dari pabrik memiliki fungsi yang kurang dalam menunjang tumbuh kembang anak. Alat permainan tersebut antara lain kartu bergambar, manusia karet, Video games, mainan elektronik dan mainan yang berbasis komputer lainnya. Salah satu contoh permainan elektronik seperti permainan berupa pertarungan atau pertandingan/tinju, dengan gambar animasi pahlawan, hanya akan menananamkan sifat-sifat kekerasan, sebab anak cenderung akan meniru apa yang dilihat. Kemudian permainan kartu bergambar hanya akan menanamkan sifat judi dalam diri anak. Penelitian ini bertujuan untuk mengetahuai hubungan pendidikan, \& sumber Informasi terhadap Pengetahuan Ibu Yang Mempunyai Balita Tentang Alat Permainan Yang Dapat Merangsang Perkembangan Motorik Balita Di Wilayah Kerja Puskesmas Hutaimbaru.

Metode yang digunakan yaitu penelitian survei analitik dengan pendekatan Cross Sectional. Populasi dalam penelitian ini sebanyak 115 orang ibu yang mempunyai balita dan sampel sebanyak 30 orang. Alat ukur menggunakan kuesioner, analisis data menggunakan uji chi square.

Hasil penelitian menunjukkan hasil uji chi-square menunjukkan ada hubungan pendidikan dengan nilai $\mathrm{p}=0,009<0.005$, dan tidak ada hubungan sumber informasi dengan nilai $\mathrm{p}=0,169>0.005$ terhadap Pengetahuan Ibu Yang Mempunyai Balita Tentang Alat Permainan Yang Dapat Merangsang Perkembangan Motorik Balita.
\end{abstract}

Kata kunci: Pendidikan, Sumber Informasi , Alat permainan

\section{ABSTRACT}

Game tools have a considerable influence on children's growth and development. However, in reality the games that spread in the community are mostly dominated by noneducational games, so that many toys produced from factories have less function in supporting children's growth and development. These games include picture cards, contortionists, video games, electronic toys and other computer-based toys. One example of electronic games such as games in the form of fighting or fighting / boxing, with animated images of heroes, will only instill violent traits, because children tend to imitate what they see. Then the picture card game will only instill the nature of gambling in the child. This study aims to determine the relationship between education and information sources on the 
knowledge of mothers who have toddlers about game tools that can stimulate toddler motor development in the working area of the Hutaimbaru Health Center.

The method used is analytical survey research with a cross sectional approach. The population in this study were 115 mothers who have children under five and a sample of 30 people. Measuring tool using a questionnaire, data analysis using the chi square test. The results showed that the results of the chi-square test showed that there was a relationship between education and $p=0.009<0.005$, and there was no relationship between information sources and $p=0.169>0.005$ on the knowledge of mothers who have toddlers about game tools that can stimulate toddler motor development

Keywords: Education, Information Sources, Game Tools

\section{Pendahuluan}

Masa balita merupakan salah satu periode penting dalam tumbuh kembang anak, terutama pada usia 1-3 tahun, karena pada masa ini otak anak akan lebih cepat menyerap segala sesuatu yang diterima dari rangsangan luar (Mahmud, 2010).

Hasil penelitian yang dilakukan Montessorri, mengatakan bahwa pertumbuhan dan perkembangan sel jaringan otak pada usia 3 tahun pertama sudah mencapai $80 \%$. Pertumbuhan volume otak terjadi hanya saat fase 1-3 tahun dan perkembangannya bersifat permanen. Sedangkan $20 \%$ sisanya akan terjadi pada usia berikutnya dan bersifat meneru skan perkembangan y ang telah terbentuk ketika usia 1-3 tahun. Oleh karena itu baik buruknya sikap anak, tinggi rendahnya kecerdasan anak, aktif pasifnya kegiatan motorik anak, akan dibentuk dan ditentukan ketika u sia 1 -3 tahun (Anwar, 2003). Artinya, bila pada usia tersebut otak anak tidak mendapatkan rangsangan/stimulasi yang maksimal, maka otak anak tidak akan berkembang secara optimal (Su yadi, 2009).

Bermain bagi anak usia dini sangatlah penting, dengan bermain maka proses belajar akan efektif dan lebih cepat ditangkap pada saat mereka bermain serta salah satu manfaat dari bermain baik untuk pengembangan kognitif anak (Fadlillah, 2014).

Penggunaan alat bantu dalam kegiatan bermain pada usia 1-3 tahun dapat menjadi stimulus yang sangat diperlukan untuk merangsang perkembangan kognitif, motorik, kecerdasan, bahasa, dan adaptasi sosial (Suherman, 2010). Berbagai data dan penelitian menyatakan bahwa bermain dengan menggunakan alat bantu $70 \%$ lebih efektif dibandingkan dengan tidak menggunakan alat bantu untuk perkembangan otak anak di 3 tahun pertama usianya (Bermain Stimulus, 2010).

Data Riset Internasional tahun 2006 ketika dilakukannya Research Playand PhysicalQuotient atau Riset Kemampuan fisik dan Bermain anak menunjukkan bahwa Indonesia menjadi urutan terend ah dibandingkan Thailand, Vietnam dan Jepang. Dalam hal ini juga terungkap bahwa aktivitas yang paling sering dilakukan anak-anak adalah menonton TV daripada bermain dengan menggunakan alat permainan yang bersifat edukatif (Sriamin, 2006). Menurut DepKes RI (2006), bahwa 0,4 juta (16\%) balita Indonesia mengalami gangguan perkembangan, baik perke mbangan motorik kas ar maupun halus, gangguan pendengaran, kecerdasan kurang dan keterlambatan bicara.

Berdasarkan survei pendahuluan yang dilakukan oleh peneliti di Puskesmas Hutaimbaru dari 15 ibu yang di wawancarai tidak ada satu pun yang mengetahui tentang Alat Permainan Yang Dapat Merangsang Perkembangan Motorik Pada Balita. Berdasarkan dari hal tersebut maka penulis tertarik untuk melakukan penelitian dengan judul "Hubungan Pendidikan dan sumber in formasi terhadap Pengetahuan Ibu Yang Mempunyai Balita Tentang Alat Permainan Yang Dapat Merangsang Perkembangan Motorik Pada Balita Di wilayah kerja Puskesmas Hutaimbaru.

Penelitian ini bertujuan untuk mengetahui Hubungan Pendidikan dan sumber informasi terh ad ap Pengetahuan Ibu Yang Mempunyai Balita Tentang Alat Permainan Yang Dapat Merangsang Perkembangan Motorik Pada Balita Di wilayah kerja Puskesmas Hutaimbaru. 


\section{MetodePenelitian}

Penelitian yang digunakan adalah penelitian survey analitik, dengan pendekatan Cross Sectional. Populasi dalam penelitian ini yaitu seluruh ibu yang mempunyai balita di Puskesmas Hutaimbaru berjumlah sebanyak 115 orang. Dan jumlah sampelnya adalah 30 responden. Anlias data yang digunakan adalah Analisa Univariat dan bivariat.

\section{Hasil dan Pembahasan}

1. Hubungan Pendidikan Terhadap Pengetahuan Ibu Yang Mempunyai Balita Tentang Alat Permainan Yang Dapat Merangsang Perkembangan Motorik Pada Balita Di Wilayah Kerja Puskesmas Hutaimbaru

Table 1 Hubungan Pendidikan Terhadap Pengetahuan Ibu

\begin{tabular}{|c|c|c|c|c|c|c|c|}
\hline \multirow{3}{*}{ Pendidikan } & \multicolumn{4}{|c|}{ Pengetahuan } & \multirow{2}{*}{\multicolumn{2}{|c|}{ Total }} & \multirow{3}{*}{$P$} \\
\hline & \multicolumn{2}{|c|}{ Baik } & \multicolumn{2}{|c|}{ Kurang } & & & \\
\hline & $\bar{n}$ & $\%$ & n & $\%$ & $\bar{n}$ & $\%$ & \\
\hline Tinggi & 5 & 50 & 5 & 50 & 10 & 100,0 & \multirow{3}{*}{0.009} \\
\hline Rendah & 1 & 5 & 19 & 95 & 20 & 100,0 & \\
\hline Total & 6 & 20 & 24 & 80 & 30 & 100,0 & \\
\hline
\end{tabular}

Berdasarkan tabel diatas menunjukkan bahwa pendidikan tinggi responden yang berpendidikan tinggi dan berpengatuhuan baik sebnayak 5 orang $(50 \%)$ dan pengetahuan kurang 5 orang $(50 \%)$. Sedangkan responden yang mepunyai Pendidikan rendah dan pengetahuan baik sebanyak 1 orang (5\%) dan pengetahuan kurang sebnayak 19 orang (95\%).

Hasil uji chi-square menunjukkan $\mathrm{p}=0.009<0.05$ yang artinya ada hubungan pendidikan terhadap pengetahuan ibu yang mempunyai balita tentang alat permaianan yang dapat merangsang perkembangan motorik balita.

Pendidikan berarti bimbingan yang di berikan seseorang agar dapat memahami sesuatu hal. Semakin tinggi pendidikan seseorang, makin mudah pula mereka menerima informasi dan pengetahuan yang dimilikinya semakin banyak (Mubarak, 2011).

Penelitian ini sejalan dengan pendapat Mahyub (2010) yang mengatakan bahwa pendidikan seseorang juga dapat mempengaruhi tingkat pengetahuan yang dimiliki.Pendidikan diperlukan untuk mendapat informasi misalnya hal-hal yang menunjang kesehatan sehingga dapat meningkatkan kualitas hidup.

Dalam memilih alat permainan tidak terlepas kaitannya dengan pengetahuan yang dimiliki oleh orang tua, terutama ibu, yang menjadi orang terdekat dan pendidik pertama di dalam lingkungan keluarga. Hal ini menjadi penting karena idealnya, jika pengetahuan terhadap alat permainan baik maka dalam memilih alat permainan tidak akan sembarangan melainkan akan lebih selektif, baik dilihat dari segi keamanan benda/alat bermain, bentuk yang dapat merangsang perkembangan, warna, dan manfaatnya. Begitu juga sebaliknya jika pengetahuan terhadap alat permainan kurang maka dalam pemilihannya pun tidak terlalu selektif sehingga pertumbuhan dan perkembangan anak menjadi tidak optimal.

Menurut asumsi peneliti bahwa pendidikan yang tinggi dapat menjadikan pengetahuan juga semakin baik. Pengetahuan yang baik akan menghasilakan sikap yang baik dalam memikirkan tentang pertumbuhan dan perkembangan balitanya sehingga balita tersebut dapat berkembang sesuai dengan yang seharusnya. 
2. Hubungan Sumber Informasi Terhadap Pengetahuan Ibu Yang Mempunyai Balita Tentang Alat Permainan Yang Dapat Merangsang Perkembangan Motorik Pada Balita Di Wilayah Kerja Puskesmas Hutaimbaru

Tabel 2 Hubungan Sumber Informasi Terhadap Pengetahuan Ibu

\begin{tabular}{|c|c|c|c|c|c|c|c|}
\hline \multirow{3}{*}{$\begin{array}{l}\text { SumberInforma } \\
\text { si }\end{array}$} & \multicolumn{4}{|c|}{ Pengetahuan } & \multirow{2}{*}{\multicolumn{2}{|c|}{ Total }} & \multirow{3}{*}{$P$} \\
\hline & \multicolumn{2}{|c|}{ Baik } & \multicolumn{2}{|c|}{ Kurang } & & & \\
\hline & $\mathbf{n}$ & $\%$ & $\bar{n}$ & $\%$ & $\mathbf{n}$ & $\%$ & \\
\hline Media Cetak & 2 & 50 & 2 & 50 & 4 & 100,0 & \multirow{3}{*}{0.169} \\
\hline Media Elektronik & 4 & 15,4 & 22 & 84,6 & 26 & 100,0 & \\
\hline Total & 6 & 20 & 24 & 80 & 30 & 100,0 & \\
\hline
\end{tabular}

Berdasarkan tabel diatas menunjukkan bahwa responden memperoleh sumber informasi dari media cetak dan berpengatuhan baik sebanyak 2 orang (50\%) dan pengetahuan kurang 2 orang (50\%). Sedangkan Responden memperoleh sumber informasi dari media elektronik danberpengetahuan baik 4 orang $(15,4 \%)$ dan yang berpengetahuan kurang sebanyak 22 orang $(84,6 \%)$.

Hasil uji chi-square menunjukkannilai $\mathrm{p}=0.169>0.005$ yang artinya tidak ada pengaruh su mber informasi terhadap pengetahuan ibu yang mempunyai balita tentang alat permaianan yang dapat merangsang perkembangan motorik balita.

Menurut Notoadmodjo (2003), hal yang didapat tentang informasi, baik itu terbaru maupun yang lama. Dimana bertujuan untuk meningkatkan pengetahuan masyarakat sehingga seseorang yang lebih banyak mencari informasi baik dari media cetak, media elektronik, maupun petugas kesehatan, maka pengetahuan lebih tinggi dari pada orang yang tidak pernah menerima informasi dari satu sumber informasi saja, maka pengetahuan yang diperoleh masih dianggap kurang.

Menurut asusmsi peneliti bahwa tidak selamanya informasi dapat di peroleh dari media cetak atau media elektrik.Sumberi informasi yang di peroleh ibu bisa saja dari tetangga atau melalui mulut ke mulut.

\section{KESIMPULAN}

Adapun kesimpulan penelitian ini adalah Ada hubungan antara pengaruh pendidikan terhadap pengetahuan ibu yang mempunyai balita tentang alat permainan yang dapat merangsang perkembangan motorik balita $\mathrm{p}=0,029<0,005$.

Tidak ada hubungan antara pengaruh sumber informasi terhadap pengetahuan ibu yang mempunyai balita tentang alat $\mathrm{p}=0,169>0,005$.

\section{DAFTAR PUSTAKA}

Mahmud. (2010). Bermain Cerdaskan Emosi Anak.Jakarta : Salemba Medika

Musbikin, I. (2010). Buku Pintar Paud. Jakarta: Laksana

Nursalam.(2008). Konsep dan Penerapan Metodologi Penelitian Ilmu Keperawatan.Surabaya : Salemba Medika

Profil Dinas Kesehatan Kota Ponorogo, (2014), dalam Haslina. 2018. Hubungan Pengetahuan Dan Sikap Ibu Dengan Pemilihan Alat Permainan Untuk Menstimulasikan Tumbug Kembang AnakToddler Di Paud Al-Khanza Kecamatan Kota Juang Kabupaten Bireuen Tahun 2014.https://HASLINA-jurnal.pdf\#page=1\&zoom=auto,-82,843Diakses. (20 April 2018). 
Ronald. (2010). Pola Asuh dan Peran Orang Tua bagi Anak.Jakarta : Rineka Cipta. (2006). Peran Orang Tua Dalam Meningkatkan Kualitas Hidup, Mendidik, dan Mengembangkan Moral Anak.Bandung: Yrama Widya

Supartini, Y. (2004). dalam Haslina. 2018. Hubungan Pengetahuan Dan Sikap Ibu Dengan Pemilihan Alat Permainan Untuk Menstimulasikan Tumbug Kembang AnakToddler Di Paud Al-Khanza Kecamatan Kota Juang Kabupaten Bireuen Tahun 2014.https://HASLINA-jurnal.pdf\#page=1\&zoom=auto,-82,843Diakses. (20 April 2018).

Hidayat, A. (2007). Kesehatan Ibu dan Anak dalam Haslina.2018. Hubungan Pengetahuan Dan Sikap Ibu Dengan Pemilihan Alat Permainan Untuk Menstimulasikan Tumbug Kembang AnakToddler Di Paud Al-Khanza Kecamatan Kota Juang Kabupaten Bireuen Tahun 2014.https://HASLINA-jurnal.pdf\#page=1\&zoom=auto,-82,843Diakses. (20 April 2018).

Sujardi, (2005).Kesehatan Ibu dan Anak dalam Haslina.2018. Hubungan Pengetahuan Dan Sikap Ibu Dengan Pemilihan Alat Permainan Untuk Menstimulasikan Tumbug Kembang AnakToddler Di Paud Al-Khanza Kecamatan Kota Juang Kabupaten Bireuen Tahun 2014.https://HASLINA-jurnal.pdf\#page=1\&zoom=auto,-82,843Diakses. (20 April 2018).

Ismail, (2009).Kesehatan Ibu dan Anak dalam Haslina.2018. Hubungan Pengetahuan Dan Sikap Ibu Dengan Pemilihan Alat Permainan Untuk Menstimulasikan Tumbug Kembang AnakToddler Di Paud Al-Khanza Kecamatan Kota Juang Kabupaten Bireuen Tahun 2014.https://HASLINA-jurnal.pdf\#page=1\&zoom=auto,-82,843Diakses. (20 April 2018).

Hidayat, (2005).Kesehatan Ibu dan Anak dalam Haslina.2018. Hubungan Pengetahuan Dan Sikap Ibu Dengan Pemilihan Alat Permainan Untuk Menstimulasikan Tumbug Kembang AnakToddler Di Paud Al-Khanza Kecamatan Kota Juang Kabupaten Bireuen Tahun 2014.https://HASLINA-jurnal.pdf\#page=1\&zoom=auto,-82,843Diakses. (20 April 2018).

(2007). Kesehatan Ibu dan Anak dalam Haslina.2018. Hubungan Pengetahuan Dan Sikap Ibu Dengan Pemilihan Alat Permainan Untuk Menstimulasikan Tumbug Kembang AnakToddler Di Paud Al-Khanza Kecamatan Kota Juang Kabupaten Bireuen 